\title{
Effect of the Type of Pasture on the Meat Characteristics of Chilote Lambs
}

\author{
Jorge Ramírez-Retamal1,2, Rodrigo Morales ${ }^{2 *}$, M. Eugenia Martínez ${ }^{3}$, Rodrigo de la Barra3 \\ ${ }^{1}$ Escuela de Graduados, Facultad Ciencias Agrarias, Universidad Austral de Chile, \\ Becario CONICYT, Valdivia, Chile \\ ${ }^{2}$ Instituto de Investigaciones Agropecuarias (INIA), Osorno, Chile \\ ${ }^{3}$ Instituto de Investigaciones Agropecuarias (INIA), Castro, Chile \\ Email: "rmorales@inia.cl
}

Received 18 December 2013; revised 18 January 2014; accepted 25 January 2014

Copyright $(2014$ by authors and Scientific Research Publishing Inc.

This work is licensed under the Creative Commons Attribution International License (CC BY).

http://creativecommons.org/licenses/by/4.0/

(c) (i) Open Access

\begin{abstract}
Chilote sheep are a native breed from Chiloé Archipelago in the southern Chile. They are descendants from sheep originally introduced by the Spaniards in the 1600s, and then evolved in a harsh environment in relative isolation from the continent. There is little information about the quality of the meat of the Chilote lambs (Ch). The objective of this study was to compare the quality of Ch lamb meat with two types of marginal pastures. The two treatments were: 1) Ch lambs, naturalized grassland $(n=13)$ and 2$)$ Ch lambs, rangeland $(n=11)$. Rangeland is composed of both grasses and native shrubs. All lambs were kept with their mothers until slaughter at 90 days of age. Instrumental color, shear force, $\mathrm{pH}$ levels, and chemical and fatty acid content were analyzed. The pasture type did affect the results, given that $\mathrm{Ch}$ lambs fed on naturalized pasture had a lower shear force and higher intramuscular fat levels whereas $\mathrm{Ch}$ lambs fed on rangeland pasture showed higher percentages of $n-3, n-6$ fatty acids and Polyunsaturated fatty acids. However, the concentrations of fatty acids were similar in both groups. The results indicated some evidences that the type of pasture of Chiloe archipelago confers specific differences of quality that could form the basis to generate a premium product.
\end{abstract}

\section{Keywords}

Rangeland; Feeding; Quality; Fatty Acids

\section{Introduction}

In recent years, meat quality has gained greater importance in consumers, producers and the industry [1]. Meat

\footnotetext{
${ }^{*}$ Corresponding author.
} 
quality is evaluated by consumers by means of a series of factors, such as visual and sensorial properties and safety [2]. However, quality can also be determined more objectively through properties of the meat, like $\mathrm{pH}$ level [3], color [4], tenderness [1] and chemical composition. More attention is also paid to fatty acid concentrations given their importance for human health [5].

The age, sex, and breed of the animal and the type of feed are some of the factors that can affect the quality of the sheep meat [6]-[10]. The $\mathrm{pH}$ level of the lamb meat does not appear to be affected by feed type [11]. However, color is affected, presenting a darker color when the animal has been fed by grazing compared with the meat of animals fed with concentrates [4]. Likewise, the meat of lambs fed with concentrates is tenderer owing to more fattening [12]. The fatty acid profile can also be altered by the type of feed. Animals fed by grazing have higher concentrations of polyunsaturated fatty acids [13] [14]. As well, grazing systems increase concentrations of conjugated linoleic acid (CLA), which has been shown to have anticancer, anti-diabetes and antiadipogenic effects among others [14] [15]. Although there are different feeding systems (concentrates, pasture or mixed), pasture-based feeding has acquired importance because resulting meat products are viewed by consumers as more natural, healthier, less contaminated and more respectful to animal welfare [16] [17]. Because of this perception, there have been several studies [18]-[20] to determine if the type of pasture and pasture composition affects the quality of ovine meat. To date, there is little information about Chilote lamb meat quality. In addition, there is relatively little information available on the differences in lamb meat quality produced on marginal pastures. In this sense, the aim of the present study was to determine the effect of feeding on two types of marginal pastures on the main indicators of quality in ovine meat of sheep raised in the Chiloe archipelago.

\section{Materials and Methods}

\subsection{Animals and Experimental Design}

The study was carried out at the Butalcura INIA Experimental Center (latitude $42^{\circ} 15$ 'S ; longitude $73^{\circ} 39^{\prime} \mathrm{W}$ ) on Chiloé Island. The island has a mean annual rainfall of $2.070 \mathrm{~mm}$, with mean temperatures of $10.7^{\circ} \mathrm{C}$. The assay was conducted from September to December 2011.

Twenty-four lambs were selected from the offspring of a group of 180 females of Chilote breed that had been estrus synchronized with an intravaginal device (Easy-Breed CIDR ${ }^{\circledR}$, Pzifer ${ }^{\circledR}$ ). All were males, with no more than $48 \mathrm{~h}$ difference in age. All the lambs were from single-offspring births and all the lambs had the same male parent. The lambs were kept with their mothers until they were slaughtered at approximately 90 days of age. The animals were assigned to one of two experimental groups according to their birth weight. The first group was composed of $13 \mathrm{Ch}$ lambs and the second of 11 Ch lambs.

Experimental group 1 was fed on naturalized pasture with seven-day rotational grazing in one-hectare paddocks with an animal load of five sheep per hectare. Experimental group 2 was fed on rangeland pasture with a five-day rotational grazing in one-hectare paddocks. The animal load was five sheep per hectare. Table 1 shows the botanical composition of the two types of pasture. Proximal chemical and botanical analyses were made periodically of both pasture types, with a total of 8. Samples were cut from ground level from 1-m-long by 0.5meter-wide exclusion cages. The samples were then sent to the INIA Remehue Animal Nutrition and Environment

Table 1. Botanic composition of naturalized and rangeland type pasture expressed as percentage/100 grams of sample.

\begin{tabular}{ccc}
\hline & \multicolumn{2}{c}{ Pasture } \\
\hline Botanic composition (\%) & Naturalized & Rangeland \\
\hline Agrostis capillaris L. & 8.76 & 12.20 \\
Berberis buxifolia Lam. & 0.00 & 1.06 \\
Gaultheria phillyreifolia (Pers.) Sleumer & 0.00 & 38.24 \\
Holcus lanatus L. & 77.68 & 24.33 \\
Lolium perenne L. & 4.76 & 0.00 \\
Plantago lanceolata L. & 2.82 & 6.44 \\
Trifolium repens L. & 1.65 & 1.42 \\
Others & 4.33 & 16.31 \\
\hline
\end{tabular}


Laboratory in Osorno, Chile.

\subsection{Slaughter and Instrumental Measurements}

Once the lambs had been weaned they were weighed to obtain their live weight (LW) and were then taken to a commercial slaughterhouse (MAFRISUR ${ }^{\circledR}$, Osorno, Chile) $24 \mathrm{~h}$ before slaughter, with access to water ad libitum. The lambs were slaughtered by stunning and then skinned and eviscerated. The carcasses were kept in cold storage for $24 \mathrm{~h}$ at $4^{\circ} \mathrm{C} \pm 2^{\circ} \mathrm{C}$. Afterwards, the carcasses were cut lengthwise along vertebral column into half carcasses (right and left) and then deboned. Following deboning, instrumental color was measured $(24 \mathrm{~h})$ with the CIELAB system $[21]\left(\mathrm{D}_{65} ; 10^{\circ} \mathrm{C}\right)$ with a colorimeter (CR-400, Konica Minolta, Japan) in the left longissimus dorsi muscle at the level of the $9^{\text {th }}$ to $13^{\text {th }}$ vertebras. Color measurement was also employed to determine the chromaticity. The muscles were subsequently vacuum packed and frozen at $-18^{\circ} \mathrm{C} \pm 2^{\circ} \mathrm{C}$ until analysis at the Food Quality and Sensorial Analysis Laboratory of INIA Remehue.

\subsection{Color, $\mathrm{pH}$ and Texture}

The samples were thawed for analysis for $48 \mathrm{~h}$ at $4{ }^{\circ} \mathrm{C} \pm 2^{\circ} \mathrm{C}$, after which instrumental color was measured again $(\mathrm{PF})$. The samples were then kept at room temperature for 30 minutes before measuring $\mathrm{pH}$ levels with a $\mathrm{pH}-$ meter (HI 99163, HANNA Instruments, Spain) with a penetration electrode (FC 232, HANNA Instruments, Spain).

To analyze texture, the samples were cut into 3-cm steaks and the external fat was removed. The steaks were cooked in an oven at $170^{\circ} \mathrm{C}$ until reaching a central temperature of $73^{\circ} \mathrm{C} \pm 1^{\circ} \mathrm{C}$ (approximately 15 minutes). After being cooked, the steaks were chilled at $4^{\circ} \mathrm{C} \pm 2^{\circ} \mathrm{C}$ for $24 \mathrm{~h}$. Some 6 to $101.3-\mathrm{cm}$ circular specimens were extracted with a hollow punch to measure shear force with a Texture Analyzer (TA-XT2i, Stable Micro Systems, United Kingdom) using the Warner-Bratzler method (WBSF) [22] at a crosshead speed of $1 \mathrm{~mm} / \mathrm{s}$, yielding the shear force (kgf).

\subsection{Chemical Analysis}

Some $100 \mathrm{~g}$ of sample were chemically analyzed at the Animal Nutrition and Environment Laboratory of INIA Remehue in Osorno, Chile. The variables analyzed were intramuscular Fat (IMF) and the minerals phosphorous $(\mathrm{P})$, calcium $(\mathrm{Ca})$, magnesium $(\mathrm{Mg})$, sodium $(\mathrm{Na})$, and potassium $(\mathrm{K})$, expressed as percentages of wet matter. As well, the minerals zinc $(\mathrm{Zn})$, copper $(\mathrm{Cu})$, iron $(\mathrm{Fe})$, manganese $(\mathrm{Mn})$ and boron $(\mathrm{B})$ expressed as parts per million (ppm) of the sample. In order to quantify Intramuscular Fat (IMF) from meat samples, all external fat was removed from meat samples. Samples were dried at $60^{\circ} \mathrm{C} \pm 2^{\circ} \mathrm{C}$ by $48 \mathrm{~h}$ and ground before analysis. IMF was measured by Soxhlet extraction 920.39 method [23] whereas Atomic absorption spectrophotometry was used for the mineral analysis in accordance with Sadzawka, 2007 [24].

To determine the fatty acid, $10 \mathrm{~g}$ of fresh sample was for content in the meat, and $35 \mathrm{gr}$ to determine the content in fresh pasture. Fat extraction method was performed according to Bligh and Dyer, 1959 [25] and modified by Lumley and Colwell, 1991 [26]. In the case of the meat the methylation was done in accordance with Ichihara, 1996 [27] whereas Hartman and Lago, 1973 [28] was used for the pasture samples. The samples were analyzed with gas chromatography (Shimadzu model GC 2010 Plus) equipped with an FID detector. A capillary column (SP ${ }^{\mathrm{tm}}-2560$, Sigma-Aldrich, USA, $100 \mathrm{~m} \times 0.25 \mathrm{~mm} \times 0.2 \mu \mathrm{m}$ ) was used for gas separation, with an initial oven temperature of $140^{\circ} \mathrm{C}$, increasing by $4^{\circ} \mathrm{C} \cdot \mathrm{min}^{-1}$ until reaching $240^{\circ} \mathrm{C}$. The temperatures of the injector and detector were $260^{\circ} \mathrm{C}$, using helium as a gas carrier at a flow rate of $0.5 \mathrm{~mL} \cdot \mathrm{min}^{-1}$, with a split of $100: 1$. The external standard used was a mix of fatty acid methyl esters (Supelco 37 Component FAME Mix, Supelco Analytical, USA), CLA ethyl ester (9c,11tr-Octadecadienoic, Larodan Fine Chemicals, Sweden), trans-11-vaccenic methyl ester (Perkin Elmer, USA), PUFA-2 (Supelco Analytical, USA) and C19 as an internal standard (NUCheckPrep, INC, Elysian, USA).

\subsection{Statistical Analysis}

Data were analysed by ANOVA with type of diet was considered as fixed effect. In the case of instrumental color, type diet and time were considered as fixed effects. The analyses were perfomed in the Statgraphics Centurion XV program, version 15.02.6 (StatPoint, 2007). 


\section{Results and Discussion}

\subsection{Pastures}

Table 2 presents the results of the proximal chemical analysis and the percentages of the different fatty acids for the two pasture types of the two pasture types. There were significant differences $(P<0.05)$ for all the variables analyzed except NDF (\%) and ash (\%). The naturalized pasture had a lower DM (\%) than the rangeland pasture but higher values for the other variables, most notably the higher percentage of EE. There were significant differences $(P<0.05)$ for all the fatty acids analyzed with the exception of C18:2 $n-6 c$. Naturalized pasture had a higher percentage of C18:3n-3 whereas the rangeland pasture had a higher percentage of C18:1 n-9c.

The differences in the percentages of the different types of fatty acid owing pasture types could be associated with the botanic composition of the pastures (Table 1) [18]. The fatty acid levels obtained with naturalized pasture were similar those obtained with different pasture types by Aurousseau, 2004 [29], Lourenço, 2007 [18], and Prache, 2011 [20], with the exception of palmitic acid, which presented higher values with both pasture types. Likewise, Aurousseau, 2007 [7] found markedly lower values for all the fatty acids analyzed in meat of animals fed on natural pasture. Macías, 2011 [30] reported similar palmitic acid values in a naturalized pasture to what we found for rangeland pasture.

\subsection{Effect of Type of Pasture}

Table 3 shows the LW, WCW and CCW values, which were discussed previously by Ramírez-Retamal, 2013 [31].

Table 2. Average and standard deviation of proximal chemical analyses and fatty acid profiles (\% of total fatty acids) of naturalized and rangeland pasture.

\begin{tabular}{ccc}
\hline & & \\
\hline Chemical analysis & Naturalized & Pasture \\
\hline DM (\%) & $16.3 \pm 2.96^{\mathbf{b}}$ & $23.77 \pm 4.88^{\mathbf{a}}$ \\
CP (\%) & $20.33 \pm 3.69^{\mathbf{a}}$ & $12.61 \pm 2.52^{\mathbf{b}}$ \\
Dig (\%) & $77.81 \pm 10.27^{\mathbf{a}}$ & $56.98 \pm 10.24^{\mathbf{b}}$ \\
ME (Mcal/kg) & $2.57 \pm 0.28^{\mathbf{a}}$ & $1.93 \pm 0.3^{\mathbf{b}}$ \\
NDF (\%) & $52.11 \pm 4.19$ & $54.97 \pm 2.72$ \\
Ash (\%) & $8.51 \pm 1.99$ & $7.73 \pm 1.19$ \\
EE (\%) & $2.16 \pm 0.24^{\mathbf{a}}$ & $1.63 \pm 0.25^{\mathbf{b}}$ \\
DV (\%) & $70.48 \pm 8.75^{\mathbf{a}}$ & $50.93 \pm 9.26^{\mathbf{b}}$ \\
N (\%) & $3.25 \pm 0.59^{\mathbf{a}}$ & $2.01 \pm 0.41^{\mathbf{b}}$ \\
Fatty acids (\%) & \\
C16 & $21.22 \pm 3.83^{\mathbf{b}}$ & $31.40 \pm 4.13^{\mathbf{a}}$ \\
C18 & $3.17 \pm 0.67^{\mathbf{b}}$ & $6.33 \pm 1.74^{\mathbf{a}}$ \\
C18:1 n-9c & $4.41 \pm 1.55^{\mathbf{b}}$ & $10.10 \pm 1.82^{\mathbf{a}}$ \\
C18:2 n-6c & $14.49 \pm 2.54$ & $16.91 \pm 2.49$ \\
C18:3 n-3 & $59.30 \pm 5.02^{\mathbf{a}}$ & $39.73 \pm 9.93^{\mathbf{b}}$ \\
\hline
\end{tabular}

${ }^{\mathbf{a}, \mathbf{b}}$ Different letters among columns indicate statistically significant differences $(P<0.05)$. DM: dry matter; CP: crude protein; Dig: in vitro digestibility; ME: metabolizable energy; NDF: neutral detergent fiber; EE: ether extract; DV: digestability value; $\mathrm{N}$ : nitrogen.

Table 3. Average and standard deviation of live weight (LW), warm carcass weight (WCW), cold carcass weight (CCW) in lambs with different types of pasture.

\begin{tabular}{ccc}
\hline & & \\
& & Pasture \\
& Naturalized & Rangeland \\
\hline LW $(\mathrm{kg})$ & $28.20 \pm 6.22$ & $26.89 \pm 3.74$ \\
WCW $(\mathrm{kg})$ & $12.12 \pm 3.11$ & $11.04 \pm 1.78$ \\
CCW $(\mathrm{kg})$ & $11.54 \pm 3.02$ & $10.51 \pm 1.74$ \\
\hline
\end{tabular}


There was no significant difference $(P>0.05)$ owing to the effect of pasture type for $\mathrm{pH}$, both groups presenting an average $\mathrm{pH}$ level of 5.5 (Table 4). The results are within normal parameters, considering that an optimal $\mathrm{pH}$ level is below 5.8 [32]. In relation to the effect of diet on the $\mathrm{pH}$ level, Priolo, 2002 [12] found $\mathrm{pH}$ values of 5.62 in Ile de France lambs with 14-kg carcasses, with no significant differences between pasture- and concentrate-based diets. Another study [33] obtained similar $\mathrm{pH}$ values in 70-day old lambs with 12-kilo carcasses without finding differences between animals fed on forage and concentrates.

Lambs fed on naturalized pasture presented a lower average shear force (1.49 kgf) than lambs fed on rangeland pasture (1.75 kgf). The WBSF results are similar to those presented by Cañeque, 2004 [34] with Manchego breed lambs fed on maternal milk, but lower than those obtained by Sañudo, 2003 [35] in Churra breed lambs fed on grazing. According to Sañudo, 2003 [35] the animals fed by grazing, although older and therefore heavier at slaughter, yielded meat that was tenderer than that of animals fed on concentrates that reached their slaughter weight at an earlier age. The statistical differentness presented in this study between animals fed on two types of pasture could be associated with the quality of the pasture, given that the naturalized pasture is better quality (Table 2), which results in less movement by the animal to feed itself. Also, the differences in intramuscular fat (Table 4) can be associated with the WBSF results. However, these results should be associated with another more specific texture test for animal muscle that allows for obtaining more conclusive results.

The effect of pasture type presented statistically significant differences $(P<0.05)$ in IMF (Table 4), which was higher in animals fed on naturalized pasture (2.19\%) than in animals fed on rangeland pasture $(1.59 \%)$. The differences in IMF level between the two pasture types could be related with the quality of the pastures used (Table 2). The naturalized pasture had a higher level of IMF (2.16\%) than the rangeland pasture (1.63\%), which could have influenced the final IMF values in the lambs. In general these values are lower to report by McPhee, 2008 [36] in different lamb genotypes.

There is very little reference information in the case of minerals independent of the factors analyzed. The values obtained for the different minerals are similar to those described by Miguélez, 2008 [37]. The main minerals found were Fe and $\mathrm{Zn}$. This concurs with the importance assigned to these in the literature for the greater contribution of minerals to the human diet [38] and the importance of lamb meat as a source of Fe and Zn compared to plant sources is notable [39].

Table 5 shows the results for instrumental color. There were no significant differences were found for any of the analyzed variables $(P>0.05)$ based on differences in diet. For the affect of freezing on the variables $\mathrm{L}^{*}, \mathrm{a}^{*}$, $\mathrm{b}^{*}$ and chroma statistically significant differences $(P<0.05)$ were found between $24 \mathrm{~h}$ postmortem and after thawing. Compared to the results presented by Priolo, 2002 [12], both diets in this study resulted in lower luminosity $\left(\mathrm{L}^{*}\right)$ and chroma values, a higher values for a* and similar values for b*. Díaz, 2002 [33] and Velasco, 2004 [40] obtained similar $\mathrm{L}^{*}$ values to those obtained in our study in post-freezing, while values for $\mathrm{a}^{*}, \mathrm{~b}^{*}$ and

Table 4. Average and standard deviation of instrumental analyses and the compositional chemical analysis of the longissimus dorsi muscle of lambs with different type of pasture.

\begin{tabular}{ccc}
\hline & & Pasture \\
& Naturalized & Rangeland \\
\hline pH & $5.5 \pm 0.07$ & $5.5 \pm 0.05$ \\
Shear force (kgf) & $1.49 \pm 0.24^{\mathbf{b}}$ & $1.75 \pm 0.25^{\mathbf{a}}$ \\
Intramuscular Fat (\%) & $2.19 \pm 0.63^{\mathbf{a}}$ & $1.59 \pm 0.46^{\mathbf{b}}$ \\
Phosphorous (\%) & $0.21 \pm 0.02$ & $0.20 \pm 0.01$ \\
Calcium (\%) & $0.01 \pm 0.01$ & $0.01 \pm 0.01$ \\
Magnesium (\%) & $0.02 \pm 0.01$ & $0.02 \pm 0.01$ \\
Sodium (\%) & $0.07 \pm 0.01$ & $0.07 \pm 0.01$ \\
Potassium (\%) & $0.33 \pm 0.01$ & $0.34 \pm 0.02$ \\
Zinc (ppm) & $94.41 \pm 9.79$ & $91.71 \pm 9.74$ \\
Copper (ppm) & $4.65 \pm 1.57$ & $5.98 \pm 2.50$ \\
Iron (ppm) & $68.19 \pm 15.68$ & $74.83 \pm 18.25$ \\
Manganese (ppm) & $4.08 \pm 1.31$ & $3.78 \pm 1.10$ \\
Boron (ppm) & $1.65 \pm 0.24$ & $1.60 \pm 0.22$ \\
\hline
\end{tabular}

${ }^{\mathbf{a}, \mathbf{b}}$ Different letters among columns indicate statistically significant differences between pasture types $(P<0.05)$. 
Table 5. Average and standard deviation of instrumental color (mm. longissimus dorsi) of lambs with different type of pasture.

\begin{tabular}{ccccc}
\hline \multicolumn{4}{c}{ Pasture } \\
\hline & \multicolumn{2}{c}{ Naturalized } & \multicolumn{2}{c}{ Rangeland } \\
\hline $\mathrm{L}^{*}$ & $41.08 \pm 3.28$ & $38.74 \pm 3.78$ & $40.99 \pm 2.07^{\mathbf{a}}$ & $38.72 \pm 1.32^{\mathbf{b}}$ \\
$\mathrm{a}^{*}$ & $19.86 \pm 2.02^{\mathrm{a}}$ & $17.01 \pm 2.48^{\mathbf{b}}$ & $19.62 \pm 1.19^{\mathbf{a}}$ & $17.05 \pm 1.55^{\mathbf{b}}$ \\
$\mathrm{b}^{*}$ & $9.23 \pm 0.75$ & $8.66 \pm 1.39$ & $9.26 \pm 1.38$ & $8.57 \pm 0.85$ \\
Chroma & $21.89 \pm 1.85^{\mathbf{a}}$ & $19.13 \pm 2.48^{\mathbf{b}}$ & $22.66 \pm 1.54^{\mathbf{a}}$ & $19.09 \pm 1.67^{\mathbf{b}}$ \\
\hline
\end{tabular}

a,b different super-index letters among columns indicate statistically significant differences $(P<0.05)$ between color $24 \mathrm{~h}$ postmortem and after thawing. ${ }^{\text {A }}$ Post-Freezing.

chroma were lower. The aforementioned studies obtained variable results for the effect of diet on meat color. Priolo, 2002 [12] found differences in $\mathrm{L}^{*}$ and $\mathrm{b}^{*}$ between animals fed on grazing and concentrates. In contrast, Díaz, 2002 [33] only found differences in L* between lambs fed on pasture versus concentrates. In general, the meat of animals fed on pasture tends to be darker than that of animals fed on concentrates [40] owing to lower pigment concentrations in the latter. However, no study was found to compare meat lamb color between animals feeding different type of pasture.

Statistically significant differences $(P<0.05)$ were found in the affect of freezing on the variables $L^{*}, a^{*}, b^{*}$ and chroma among all the groups in the study except $L^{*}$ and $b^{*}$ in lambs fed on naturalized pasture $b^{*}$ in lambs fed on rangeland pasture. The averages of these variables were lower after freezing than at $24 \mathrm{~h}$. Freezing tends to be viewed as deteriorating meat quality [41]. Farouk and Swan, 1998 [42] described a decrease in luminosity (L*) in beef following extended periods of freezing. Likewise, Muela, 2010 [43] only found differences for b* with extended freezing (1, 3 or 6 months). According to these authors, thawing the meat directly reduces luminosity, whereas indirectly it results in the meat having a grayer rather than brownish hue owing to reduced levels of metamyoglobin reductase activity.

Tables 6 and 7 show the fatty acids composition and concentration, respectively according to the effects of pasture type. Statistically significant differences $(P<0.05)$ were C14:0, C15:0, C17:1, C18:1 n-9c, C18:2 n-6c, C20:0, C18:3 $n-3$, C20:4 $n-6$. The animals fed on naturalized pasture had higher percentages of MUFA and lower of PUFA than lambs fed on rangeland pastures. In addition, lambs fed on rangeland pastures showed higher percentages of $n-6$ and $n-3$. These results indicate a possible effect of rangeland on fatty acids profile increasing the $n-6$ and $n-3$ fatty acids. In this sense, there is litter information available on the differences in lamb quality between different botanically diverse pasture or between botanically diverse pasture and improved pasture some research indicate that meat from lambs grazing botanically diverse pastures has higher concentration of PUFA [18] whereas Gallardo, 2011 [44] did not find significant differences in fatty acids profile of meat from lambs grazing different dryland forages of Chile. In contrast, Whittington, 2006 [45] compared that lambs grazing a range of forage types including saltmarsh, heather and moorland, relative to the control which was a perennial ryegrass based systems. The control lambs had the lowest concentrations of PUFA, since fatty acid analysis of the meat revealed that heather and moorland lamb were significantly higher in all $n-6$, and in C22:6, $n-3$ and PUFA.

On the other hand, several authors have found differences in the fatty acid profiles of animals fed with different types of feed [7] [14] [33] [46]. The most common differences are between animals fed by grazing and on the other hand with concentrates, in which animals fed on grazing have a higher proportion of saturated fatty acids and Conjugated Linoleic Acid C18:2 cis-9 trans-11 (CLA) due to the forage stimulate the ruminal activity and biohydrogenation of the fatty acids [47]. The CLA values obtained in this study were similar than those presented by Whittington, 2006 [45] with lamb raised under different type of pasture and higher to those reported by Aurousseau, 2007 [7] with animals with 15-kg carcasses that had been fed with different diets (concentrates and grazing).

Regarding P:S fat ratio, this was outside the ranges recommended for human consumption [48]. A value of 0.4 or higher is recommended for the P:S ratio [49]. The P:S ratio reflects a high content of saturated fatty acids, resulting in this ratio being similar than values reported by Whittington, 2006 [45] in lambs fed on different types of pastures and higher than that obtained by Ponnampalam, 2010 [50] with animals fed on concentrates. Considerable attention has been paid to the relative proportion of n-6 and n-3 fatty acids, as diets with high 
Table 6. Average and standard deviation of relative fatty acid content (\%) in the longissimus dorsi muscle of lambs with different type of pasture.

\begin{tabular}{|c|c|c|}
\hline & \multicolumn{2}{|c|}{ Pasture } \\
\hline & Naturalized & Rangeland \\
\hline C14:0 & $4.09 \pm 0.67^{\mathrm{a}}$ & $3.07 \pm 0.50^{\mathbf{b}}$ \\
\hline C14:1 & $0.22 \pm 0.03$ & $0.24 \pm 0.05$ \\
\hline C15:0 & $0.71 \pm 0.12^{\mathrm{a}}$ & $0.58 \pm 0.07^{\mathbf{b}}$ \\
\hline C16:0 & $20.96 \pm 1.39$ & $20.08 \pm 1.09$ \\
\hline C16:1 & $0.78 \pm 0.17$ & $0.68 \pm 0.08$ \\
\hline C17:0 & $1.10 \pm 0.09$ & $1.10 \pm 0.08$ \\
\hline C17:1 & $0.62 \pm 0.15^{\mathrm{a}}$ & $0.49 \pm 0.14^{b}$ \\
\hline C18:0 & $17.16 \pm 1.72$ & $18.30 \pm 1.36$ \\
\hline C18:1 n-11t & $4.94 \pm 0.56$ & $5.33 \pm 0.87$ \\
\hline C18:1 n-9c & $34.94 \pm 2.23^{\mathrm{a}}$ & $32.01 \pm 2.58^{\mathrm{b}}$ \\
\hline C18:1 n-7 & $0.77 \pm 0.16$ & $0.88 \pm 0.10$ \\
\hline C18:2 n-6t & $0.48 \pm 0.08$ & $0.53 \pm 0.05$ \\
\hline C18:2 $n-6 c$ & $4.26 \pm 1.22^{\mathrm{b}}$ & $5.81 \pm 1.53^{\mathrm{a}}$ \\
\hline C20:0 & $0.14 \pm 0.04^{\mathbf{b}}$ & $0.20 \pm 0.02^{\mathrm{a}}$ \\
\hline C18:3 n-3 & $2.10 \pm 0.30^{\mathbf{b}}$ & $2.69 \pm 0.51^{\mathrm{a}}$ \\
\hline C18:29c $11 t$ & $2.10 \pm 0.32$ & $2.07 \pm 0.19$ \\
\hline C20:2 & $0.19 \pm 0.05$ & $0.19 \pm 0.04$ \\
\hline C22:0 & $0.39 \pm 0.15$ & $0.43 \pm 0.15$ \\
\hline C20:4 n-6 & $2.14 \pm 0.73^{b}$ & $3.20 \pm 1.13^{\mathrm{a}}$ \\
\hline C22:5 n-3 & $1.39 \pm 0.45$ & $1.51 \pm 0.55$ \\
\hline C22:6n-3 & $0.36 \pm 0.11$ & $0.46 \pm 0.13$ \\
\hline SFA & $44.56 \pm 1.79$ & $43.75 \pm 2.41$ \\
\hline MUFA & $42.27 \pm 2.43^{\mathrm{a}}$ & $39.61 \pm 2.68^{b}$ \\
\hline PUFA & $13.22 \pm 2.43^{b}$ & $16.74 \pm 3.73^{\mathrm{a}}$ \\
\hline$n-3$ & $4.60 \pm 1.02^{\mathbf{b}}$ & $6.35 \pm 1.70^{\mathrm{a}}$ \\
\hline$n-6$ & $7.03 \pm 1.14^{b}$ & $8.69 \pm 1.54^{\mathrm{a}}$ \\
\hline $\mathrm{P}: \mathrm{S}$ & $0.30 \pm 0.06^{\mathbf{b}}$ & $0.39 \pm 0.10^{\mathrm{a}}$ \\
\hline$n-6: n-3$ & $1.56 \pm 0.21^{\mathrm{a}}$ & $1.40 \pm 0.14^{\mathbf{b}}$ \\
\hline
\end{tabular}

${ }^{\mathbf{a}, \mathbf{b}}$ Different super-index letters among columns indicate statistically significant differences between pasture types $(P<$ 0.05). SFA: Saturated fatty acids: C14:0 + C16:0 + C17:0 + C18:0 + C20:0 + C22:0; MUFA: monounsaturated fatty acids: C14:1 + 16:1 + C18:1 n-9 + C18:1 n-11 trans + C18:1 n-7 + C20:1; PUFA: polyunsaturated fatty acids: C18:2 n-6 + C18:2 $n-6$ trans + C18:3 n-3 + C18:29c 11t + C20:3 n-6 + C20:2 +C20:6 n-6 + C22:5 n-3; C22:6 n-3 P:S: polyunsaturated:saturated fatty acid ratio; $n-6: n-3$ : fatty acid ratio.

Table 7. Average and standard deviation of fatty acid content (mg/g fat) in the longissimus dorsi muscle of lambs with different type of pasture.

\begin{tabular}{ccc}
\hline & & Pasture \\
\hline SFA & Naturalized & Rangeland \\
MUFA & $999.12 \pm 696.88$ & $676.82 \pm 350.15$ \\
PUFA & $939.77 \pm 676.31$ & $600.09 \pm 303.72$ \\
CLA C18:29c 11t & $255.04 \pm 134.30$ & $228.86 \pm 73.55$ \\
$n-3$ & $46.95 \pm 34.47$ & $31.27 \pm 15.90$ \\
$n-6$ & $49.22 \pm 30.19$ & $43.29 \pm 14.32$ \\
P:S & $177.08 \pm 91.59$ & $163.46 \pm 54.46$ \\
$n-6: n-3$ & $0.29 \pm 0.06^{\mathbf{b}}$ & $0.37 \pm 0.10^{\mathbf{a}}$
\end{tabular}

${ }^{\mathbf{a}, \mathbf{b}}$ Different super-index letters among columns indicate statistically significant differences between pasture types $(P<$ 0.05). SFA: Saturated fatty acids: C14:0 + C16:0 + C17:0 + C18:0 + C20:0 + C22:0; MUFA: monounsaturated fatty acids: C14:1 + 16:1 + C18:1 n-9 + C18:1 n-11 trans + C18:1 n-7 + C20:1; PUFA: polyunsaturated fatty acids: C18:2 n-6 + C18:2 $n-6$ trans + C18:3 n-3 + C18:29c 11t + C20:3 n-6 + C20:2 +C20:6 n-6 + C22:5 n-3; C22:6 n-3 P:S: polyunsaturated:saturated fatty acid ratio; $n-6: n-3$ : fatty acid ratio. 
$n-6: n-3$ ratios have been highlighted as risk factors in certain cancers and coronary heart diseases [51]. A value of 4.0 or less for a diet is recommended for the $n-6: n-3$ ratio [49]. In the present study, the two groups showed $n-6: n-3$ ratios lower than 4.0. In the case of the $n-6: n-3$ ratio, $n-3$ and $n-6$ concentrations were higher in the animals fed on rangeland pasture, resulting in a statistically significant difference.

In the present study, it is noted that animals fed on naturalized pasture had higher concentrations of the different types of fatty acid (Table 7) however, statistical differences were no found. The higher fatty acid concentrations found in this study for animals fed on naturalized pasture could be associated with differences also reflected in the proportions of IMF, which was statistically higher in the lambs fed on naturalized pasture than in animals fed on rangeland pasture.

\section{Conclusion}

The pasture type did affect the results given that Ch lambs fed on naturalized pasture had a lower shear force and higher intramuscular fat levels whereas Ch lambs fed on rangeland pasture showed higher percentages of $n-3, n-6$ fatty acids and Polyunsaturated fatty acids. However, the concentrations of fatty acids were similar in both groups. The results indicated some evidences that the type of pasture of Chiloe archipelago confers specific differences of quality that could form the basis to generate a premium product.

\section{Acknowledgements}

This work was founded by the Project "Recuperación y Desarrollo Ovino para la Provincia de Chiloé”, Regional Governement of Los Lagos, IDI Code: 30080533-0. The "CONICYT" scholarship to finance Jorge Ramirez-Retamal's master's studies (2011-2013) at the Universidad de Austral de Chile is also acknowledged. We thank Ignacio Subiabre for technical assistance. We are grateful to the slaughterhouse staff for their cooperation in the present study: Sergio Ríos and Carla Negrón at FRIMA S.A.

\section{References}

[1] Warner, R., Jacob, R., Hocking, J., McDonagh, M., Pearce, K., Geesink, G., Kearney, G., Allingham, P., Hopkins, D. and Pethick, D. (2010) Quality of Lamb Meat from the Information Nucleus Flock. Animal Production Science, 50, 1123-1134. http://dx.doi.org/10.1071/AN10129

[2] Becker, T. (2000) Consumer Perception of Fresh Meat Quality: A Framework for Analysis,” British Food Journal, 102, 158-176. http://dx.doi.org/10.1108/00070700010371707

[3] Weglarz, A. (2010) Meat Quality Defined Based on pH and Colour Depending on Cattle Category and Slaughter Season. Czech Journal Animal Science, 55, 548-556.

[4] Priolo, A., Micol, D. and Agabriel, J. (2001) Effects of Grass Feeding Systems on Ruminant Meat Colour and Flavour. A Review. Animal Research, 50, 185-200. http://dx.doi.org/10.1051/animres:2001125

[5] Givens, D. (2005) The Role of Animal Nutrition in Improving the Nutritive Value of Animal-Derived Foods in Relation to Chronic Disease. Proceedings of the Nutrition Society, 64, 395-402. http://dx.doi.org/10.1079/PNS2005448

[6] Pethick, D., Hopkins, D., D’Souza, D., Thompson, J. and Walker, P. (2005) Effects of Animal Age on the Eating Quality of Sheep Meat. Australian Journal of Experimental Agriculture, 45, 491-498. http://dx.doi.org/10.1071/EA03256

[7] Aurousseau, B., Bauchart, D., Faure, X., Galot, A., Prache, S., Micol, D. and Priolo, A. (2007) Indoor Fattening of Lambs Raised on Pasture: (1) Influence of Stall Finishing Duration on Lipid Classes and Fatty Acids in the Longissimus thoracis Muscle. Meat Science, 76, 241-252. http://dx.doi.org/10.1016/j.meatsci.2006.11.005

[8] Marino, R., Albenzio, M., Annicchiarico, G., Caroprese, M., Muscio, A., Santillo, A. and Sevi, A. (2008) Influence of Genotype and Slaughtering Age on Meat from Altamurana and Trimeticcio Lambs. Small Ruminant Research, 78, 144151. http://dx.doi.org/10.1016/j.smallrumres.2008.06.002

[9] Hopkins, D., Fogarty, N. and Mortimer, S. (2011) Genetic Related Effects on Sheep Meat Quality. Small Ruminant Research, 101, 160-172. http://dx.doi.org/10.1016/j.smallrumres.2011.09.036

[10] Komprda, T., Kuchtík, J., Jarošová, A., Dračková, E., Zemánek, L. and Filipčík, B. (2012) Meat Quality Characteristics of Lambs of Three Organically Raised Breeds. Meat Science, 91, 499-505. http://dx.doi.org/10.1016/j.meatsci.2012.03.004

[11] Lanza, M., Bella, M., Priolo, A., Barbagallo, D., Galofaro, V., Landi, C. and Pennisi, P. (2006) Lamb Meat Quality as Affected by a Natural or Artificial Milk Feeding Regime. Meat Science, 73, 313-318. http://dx.doi.org/10.1016/j.meatsci.2005.12.006 
[12] Priolo, A., Micol, D., Agabriel, J., Prache, V. and Dransfield, E. (2002) Effect of Grass or Concentrate Feeding Systems on Lamb Carcass and Meat Quality. Meat Science, 62, 179-185. http://dx.doi.org/10.1016/S0309-1740(01)00244-3

[13] Wood, J., Enser, V., Fisher, A., Nute, G., Sheard, P., Richardson, R., Hughes, S. and Whittington, F. (2008) Fat Deposition, Fatty Acid Composition and Meat Quality: A Review. Meat Science, 78, 343-353. http://dx.doi.org/10.1016/j.meatsci.2007.07.019

[14] Scerra, M., Luciano, G., Caparra, P., Foti, F., Cilione, C., Giorgi, A. and Scerra, V. (2011) Influence of Stall Finishing Duration of Italian Merino Lambs Raised on Pasture on Intramuscular Fatty Acid Composition. Meat Science, 89, 238242. http://dx.doi.org/10.1016/j.meatsci.2011.04.012

[15] Webb, E. and O’Neill, H. (2008) The Animal Fat Paradox and Meat Quality. Meat Science, 80, 28-36. http://dx.doi.org/10.1016/j.meatsci.2008.05.029

[16] Hersleth, M., Næs, T., Rødbotten, M., Lind, V. and Monteleone, E. (2012) Lamb Meat-Importance of Origin and Grazing System for Italian and Norwegian Consumers. Meat Science, 90, 899-907. http://dx.doi.org/10.1016/j.meatsci.2011.11.030

[17] Vasta, V., Pagano, R., Luciano, G., Scerra, M., Caparra, P., Foti, F., Cilione, C., Biondi, L., Priolo, A. and Avondo, M. (2012) Effect of Morning vs. Afternoon Grazing on Intramuscular Fatty Acid Composition in Lamb. Meat Science, 90, 93-98. http://dx.doi.org/10.1016/j.meatsci.2011.06.009

[18] Lourenço, M., Van Ranst, G., De Smet, S., Raes, K. and Fievez, V. (2012) Effect of Grazing Pastures with Different Botanical Composition by Lambs on Rumen Fatty Acid Metabolism and Fatty Acid Pattern of Longissimus Muscle and Subcutaneous Fat. Animal, 1, 537-545. http://dx.doi.org/10.1017/S1751731107703531

[19] Lind, V., Berg, J., Eik, L., Mølmann, J., Haugland, E., Jørgensen, M. and Hersleth, M. (2009) Meat Quality of Lamb: Pre-Slaughter Fattening on Cultivated or Mountain Range Pastures. Meat Science, 83, 706-712. http://dx.doi.org/10.1016/j.meatsci.2009.08.008

[20] Prache, S., Gatellier, V., Thomas, V., Picard, B. and Bauchart, D. (2011) Comparison of Meat and Carcass Quality in Organically Reared and Conventionally Reared Pasture Fed Lambs. Animal, 5, 2001-2009. http://dx.doi.org/10.1017/S1751731111001030

[21] Comission Internationale de l’Éclairage (CIE) (1976) Colorimetry. Publication No. 15, Bureau central de la CIE, Vienna.

[22] Bourne, M. (1978) Texture Profile Analysis. Food Technology, 32, 62-66.

[23] AOAC (2005) Official Methods of Analysis. 19th Edition, Association of Official Analytical Chemists, Washington DC.

[24] Sadzawka, A., Carrasco, M., Demanet, R., Flores, H., Grez, R., Mora, M. and Neaman, F. (2007) Métodos de Análisis de Tejidos Vegetales. Serie Actas-Instituto de Investigaciones Agropecuarias No. 40, Santiago.

[25] Bligh, E. and Dyer, W. (1959) A Rapid Method of Total Lipid Extraction and Purification. Canadian Journal of Biochemistry and Physiology, 37, 911-917. http://dx.doi.org/10.1139/059-099

[26] Lumley, I. and Colwell, R. (1991) Fats from Fatty Foods and Determination of Fat Content. In: Russell, J.B. and Pritchard, J.L.R., Eds., Analysis of Oilseeds, Fats and Fatty Foods, Elsevier, London, 227-259.

[27] Ichihara, K., Shibahara, A., Yamamoto, K. and Nakayama, T. (1996) An Improved Method for Rapid Analysis of the Fatty Acids of Glycerolipids. Lipids, 31, 535-539. http://dx.doi.org/10.1007/BF02522648

[28] Hartman, L. and Lago, R. (1973) Further Observations Concerning Effects of Unsaponifiable Constituents on the Properties of Coffee Seed Oil. Journal of the American Oil Chemists Society, 50, 99-100. http://dx.doi.org/10.1007/BF02671111

[29] Aurousseau, B., Bauchart, D., Calichon, E., Micol, D. and Priolo, A. (2004) Effect of Grass or Concentrate Feeding Systems and Rate of Growth on Triglyceride and Phospholipid and Their Fatty Acids in the M. longissimus Thoracis of Lambs. Meat Science, 66, 531-541. http://dx.doi.org/10.1016/S0309-1740(03)00156-6

[30] Macías, V. (2011) Efecto de Métodos de Conservación y Tiempo de Almacenamiento en Ensilajes en dos tipos de Pastures Sobre sus Indicadores de Calidad Nutricional. Tesis de Magister. Facultad de Ciencias Agrarias, Universidad Austral de Chile, Valdivia.

[31] Ramírez-Retamal, J., Morales, R., Martínez, M. and De la Barra, R. (2013) Effect of Breed and Feeding on the Carcass Characteristics of Chilote Breed Lamb. Chilean Journal of Agricultural Research, 73, 48-54. http://dx.doi.org/10.4067/S0718-58392013000100007

[32] Tejeda, J., Peña, R. and Andrés, A. (2008) Effect of Live Weight and Sex on Physico-Chemical and Sensorial Characteristics of Merino Lamb Meat. Meat Science, 80, 1061-1067. http://dx.doi.org/10.1016/j.meatsci.2008.04.026

[33] Díaz, M., Velasco, S., Cañeque, V., Lauzurica, S., Ruiz de Huidobro, F., Pérez, C., González, J. and Manzanares, C. 
(2002) Use of Concentrate or Pasture for Fattening Lambs and Its Effect on Carcass and Meat Quality. Small Ruminant Research, 43, 257-268. http://dx.doi.org/10.1016/S0921-4488(02)00016-0

[34] Cañeque, V., Pérez, C., Velasco, S., Díaz, M., Lauzurica, S., Alvarez, I., Ruiz de Huidobro, F., Onega, E. and De la Fuente, J. (2004) Carcass and Meat Quality of Light Lambs Using Principal Component Analysis. Meat Science, 67, 595-605. http://dx.doi.org/10.1016/j.meatsci.2004.01.002

[35] Sañudo, C., Alfonso, M., Sanchez, A., Berge, P., Dransfield, E., Zygoyiannis, D., Stamataris, C., Thorkelsson, G., Valdimarsdottir, T., Piasentier, E., Mills, C., Nute, G. and Fischer, A. (2003) Meat Texture of Lambs from Different European Production Systems. Australian Journal of Agricultural Research, 54, 551-560. http://dx.doi.org/10.1071/AR02092

[36] McPhee, M., Hopkins, D. and Pethick, D. (2008) Intramuscular Fat Levels in Sheep Muscle during Growth. Animal Production Science, 48, 904-909. http://dx.doi.org/10.1071/EA08046

[37] Miguélez, E., Zumalacárregui, J., Osorio, M., Figueira, A., Fonseca, B. and Mateo, J. (2008) Quality Traits of SucklingLamb Meat Covered by the Protected Geographical Indication “Lechazo de Castilla y León” European Quality Label. Small Ruminant Research, 77, 65-70. http://dx.doi.org/10.1016/j.smallrumres.2008.02.002

[38] Hoffman, L., Muller, M., Cloete, S. and Schmidt, D. (2003) Comparison of Six Crossbred Lamb Types: Sensory, Physical and Nutritional Meat Quality Characteristics. Meat Science, 65, 1265-1274. http://dx.doi.org/10.1016/S0309-1740(03)00034-2

[39] Williamson, C., Foster, R., Stanner, S. and Buttriss, J. (2005) Red Meat in the Diet. Nutrition Bulletin, 30, $323-355$. http://dx.doi.org/10.1111/j.1467-3010.2005.00525.X

[40] Velasco, S., Cañeque, V., Lauzurica, S., Pérez, C. and Huidobro, F. (2004) Effect of Different Feeds on Meat Quality and Fatty Acid Composition of Lambs Fattened at Pasture. Meat Science, 66, 457-465. http://dx.doi.org/10.1016/S0309-1740(03)00134-7

[41] Lagerstedt, A., Enfält, L., Johansson, L. and Lundström, K. (2008) Effect of Freezing on Sensory Quality, Shear Force and Water Loss in Beef M. longissimus dorsi. Meat Science, 80, 457-461. http://dx.doi.org/10.1016/j.meatsci.2008.01.009

[42] Farouk, M. and Swan, J. (1998) Effect of Rigor Temperature and Frozen Storage on Functional Properties of Hot-Boned Manufacturing Beef. Meat Science, 49, 233-247. http://dx.doi.org/10.1016/S0309-1740(97)00134-4

[43] Muela, E., Sañudo, C., Campo, M., Medel, I. and Beltrán, J. (2010) Effect of Freezing Method and Frozen Storage Duration on Instrumental Quality of Lamb throughout Display. Meat Science, 84, 662-669. http://dx.doi.org/10.1016/j.meatsci.2009.10.028

[44] Gallardo, M., Pulido, R. and Gallo, C. (2011) Fatty Acid Composition of longissimus dorsi Muscle of Suffolk down Lambs Fed on Different Dryland Forages. Chilean Journal of Agricultural Research, 71, 566-571. http://dx.doi.org/10.4067/S0718-58392011000400011

[45] Whittington, F., Dunn, R., Nute, G., Richardson, R. and Wood, J. (2006) Effect of Pasture Type on Lamb Product Quality. 9th Annual Langford Food Industry Conference, 'New Developments in Sheepmeat Quality', Bristol, 24-25 May, Proceedings of the British Society of Animal Science, 27-31.

[46] Demirel, G., Ozpinar, H., Nazli, B. and Keser, O. (2006) Fatty Acids of Lamb Meat from Two Breeds Fed Different Forage: Concentrate Ratio. Meat Science, 72, 229-235. http://dx.doi.org/10.1016/j.meatsci.2005.07.006

[47] Díaz, M., Alvarez, I., De la Fuente, J., Sañudo, C., Campo, M., Oliver, M., Font, M., Furnols, I., Montossi, F., San Julián, R., Nute, G. and Cañeque, V. (2005) Fatty Acid Composition of Meat from Typical Lamb Production Systems of Spain, United Kingdom, Germany and Uruguay. Meat Science, 71, 256-263. http://dx.doi.org/10.1016/j.meatsci.2005.03.020

[48] Joy, M., Alvarez-Rodriguez, J., Revilla, R., Delfam, R. and Ripoll, G. (2008) Ewe Metabolic Performance and Lamb Carcass Traits in Pasture and Concentrate-Based Production Systems in Churra Tensina Breed. Small Ruminant Research, 75, 24-35. http://dx.doi.org/10.1016/j.smallrumres.2007.07.005

[49] British Department of Health. (1994) Nutritional Aspects of Cardiovascular Disease. Report on Health and Social Subjects No. 46. Her Majesty's Stationery Office (HMSO), The National Archives, London.

[50] Ponnampalam, E., Warner, R., Kitessa, S., McDonagh, M., Pethick, D., Allen, D. and Hopkins, D. (2010) Influence of Finishing Systems and Sampling Site on Fatty Acid Composition and Retail Shelf-Life of Lamb. Animal Production Science, 50, 775-781. http://dx.doi.org/10.1071/AN10025

[51] Hibbeln, J., Nieminen, L., Blasbalg, T., Riggs, J. and Lands, W. (2006) Healthy Intakes of n-3 and n-6 Fatty Acids: Estimations Considering Worldwide Diversity. American Journal of Clinical Nutrition, 83, 1483S-1493S. 